\title{
EFFICIENCY OF VIMEK 610.2 FORWARDER AND ITS IMPACT ON SOIL IN FOREST THINNING
}

\author{
Guna PETAJA, Latvian State Forest Research Institute "Silava”, Rigas street 111, LV-2169 Salaspils, Latvia; guna.petaja@silava.lv \\ (corresponding author) \\ Edgars Muižnieks, Latvian State Forest Research Institute "Silava”, Rigas street 111, LV-2169 Salaspils, Latvia; \\ edgars.muiznieks@silava.lv \\ Santa Kalēja, Latvian State State Forest Research Institute "Silava", Rigas street 111, LV-2169 Salaspils, Latvia; \\ santa.kaleja@silava.lv
}

\begin{abstract}
Effective haulage is one of the main requirements for cost-efficient logging services. The aim of the study is to estimate productivity of Vimek 610.2 forwarder in thinning and to determine soil compaction during haulage. Trials were conducted in Latvia, in 2 forest stands located in northern part of the country, in Engure municipality. The Vimek 610.2 Biocombi harwarder with additional bunk was used as a forwarder in the trials. It was equipped with Mowi P25 crane, tracks on rear axle and net chains on front axle to enhance performance on soils with low bearing capacity. Detailed time study was implemented for 56 forwarder loads. Working time was evaluated according to working cycle of forwarder crane (13 operations in total). Productivity of Vimek 610.2 forwarder and the prime cost of roundwood forwarding under optimal and extreme conditions is determined based on the time study results. According to the results productivity of forwarder Vimek 610.2 in trials with average hauling distance of $181 \mathrm{~m}$, recalculated to productive time consumption spent to forward $1 \mathrm{~m}^{3}$ of roundwood under optimal conditions is $6.03 \mathrm{~min}$ and under extreme conditions $-6.23 \mathrm{~min}$. In soils with low bearing capacity Vimek 610.2 did not compacted soil, however formation of ruts were observed, and in areas with optimal soil bearing capacity soil compaction was detected at surface layers (down to $10 \mathrm{~cm}$ depth). Prime costs of forwarding with Vimek 610.2 under optimal conditions to $180 \mathrm{~m}$ distance is $2.46 € \mathrm{~m}^{-3}$, but under extreme conditions $-3.36 € \mathrm{~m}^{-3}$.
\end{abstract}

Keywords: forwarder, Vimek 610.2, soil compaction, productivity

\section{INTRODUCTION}

Forwarding or offroad transport is an important stage of logging and there are several factors influencing costs and environmental impact of forwarding, as well as further development of a forest stand. Productivity of forwarding is influenced by terrain, soil bearing capacity, meteorological, technological and mechanical conditions. The number of felling sites in Latvia, located on soils with low bearing capacity, is increasing along with the area of timely unthinned young stands in private forests. With increasing awareness of the possible impact of forest machines on soil (compaction, changes in water regime, increased risk of root rot spreading), requirements of soil protection are getting more strict.

According to results of the international Horizon2020 innovation project "Innovative solutions for the future of wood supply" forwarding conditions in thinning and final felling sites in Latvia during the last 5 years was extreme in $4 \%$ of areas and bad - in 35\% of areas. If all growing forests are compared, extreme conditions are possible in at least $10 \%$ of forests and bad conditions - in 33\% of forests. These results indicate that in future the need for machines that can work productively in extreme and bad conditions will increase.

Wheels of forest machines, used in mechanized logging, cause changes in soil structure. The most visible change is soil compaction resulting in deterioration of aeration of soil and water regime and negative effect on physiological processes in roots (Sarmulis, Saveljevs, 2015). Soil compaction during forwarding is influenced by pressure of wheels, number of passes, amount and arrangement of residues on strip-roads and soil bearing capacity. The ability of tree roots to grow through soil layers is one of the most important indicators characterizing impact of forest machines on soil. The threshold value of soil resistance for optimal development of roots is $1 \mathrm{MPa}$. Penetrologger cannot detect cracks and irregularity of soil structure, therefore in practice roots usually continue to grow if the penetration resistance exceeds 1 $\mathrm{MPa}$. According to a study conducted in the Netherlands, root growth continues when soil resistance is 1.5 MPa. Major growth limitations appear if soil penetration resistance reaches $3 \mathrm{MPa}$, resulting in decrease in water and nutrient uptake and reduction of increment (Smith, Mullins, 2000). Trials conducted in Sweden suggested that after intensive hauling in areas where forwarder has driven through strip roads more than 40 times, increased rate of soil compaction remains even after 10 years (Hakansson, 1985). Impact of forest machines on soil compaction and its changes over 5 years was also studied in the USA, where it was found that forest machines increases density of topsoil by $19 \%$ on strip roads and by

Copyright (C) 2017 The Authors. Published by Aleksandras Stulginskis University. This is an open-access article distributed under the terms of the Creative Commons Attribution License (CC-BY 4.0), which permits unrestricted use, distribution, and reproduction in any medium, provided the original author and source are credited. 
$10 \%$ in $1 \mathrm{~m}$ distance from strip roads, but the greatest impact was observed in depth of 20-30 cm. Cycles of freezing and thawing during 5 years had no impact on soil compaction (Labelle, Jaeger, 2011). In trials conducted in Latvia similar results were obtained, when analyzing soil compaction on strip roads 20-40 years after the final felling (Liepina et al., 2014). In several studies on soil compaction in Latvia in final felling a significant soil compaction was observed and mainly topsoil layers were compacted (Lazdiņš et al., 2008). According to a Swedish study, wheel slippage enhances destruction of tree root coating layer. Rut depth is proportional to the weight of the machine (Hallonborg, 1979). In Latvia soil penetration resistance has been studied in depth of 0-80 cm. It was concluded that soils with thick organic layer and low initial penetration resistance (low soil bearing capacity), are not subjected to the risk of soil compaction, however probability of formation of deep ruts during haulage increase with reduction of the soil penetration resistance (Prindulis, Lazdinš, 2016). In other studies conducted in Latvia it was found that significant soil compaction on strip roads in soil layers below $40 \mathrm{~cm}$ remained for several decades that slightly affected forest regeneration results, expressing as predominance of deciduous trees and decrease number of self-seeded trees on strip roads (Liepina et al., 2014).

Vimek 610.2 and Vimek 610.2 Biocombi belong to the group of small-size forwarders with 5-8 tonnes of own weight. Vimek 610.2 and similar forwarders are widely used in thinnings and selective logging in central Europe, however it is not common in Latvia. Vimek 610.2 Biocombi is built, based on Vimek 610.2 forwarder, and it can be used as a harwarder, e. i., it can act as small harvester and forwarder simultaneously. The machine is equipped with a fellingbunching head, which allows to produce biofuel from relatively large trees. Delimbing function is not considered, partially due to small size of the machine and limited capacity of hydraulic system. Vimek 610.2 Biocombi is used as a forwarder by equipping it with the standard forwarder grapple. During forwarding of logs, which are shorter than 3 m, harwarder can be equipped with additional pair of bunks. The main drawbacks of small machines are small load capacity, which significantly influences hauling costs in long distances, and relatively low level of comfort, which results in shorter shifts (Lazdin̄š, 2016). However, studies on this kind of machines, particularly, on their effective life-time, productivity, costs and ergonomic are insufficient.

In trials in Sweden the average loading productivity of Vimek 610.2 forwarder was $17.9 \mathrm{~m}^{3}$ per productive hour, but unloading productivity $-56 \mathrm{~m}^{3}$ per productive working hour. There were no technical delays during trials, therefore the proportion of productive time exceeded $90 \%$. The average driving speed was $23 \mathrm{~m} \mathrm{~min}^{-1}$ (Lazdins, 2015). When measuring soil compaction in strip roads, Italian researchers found that Vimek 610 Biocombi caused a significantly lower impact on soil in comparison with middle-class machines. When working with Vimek 610 Biocombi, soil porosity decreased from $40 \%$ to $30 \%$, but by using 2 times heavier harwarder, porosity decreased down to $20 \%$ (Spinelli et al., 2014).

During forwarding with small machines (e.g. Vimek 610.2 forwarder) the risk of soil compaction can be significantly reduced, whereas wheeled middle class forwarders in similar conditions cause significant soil compaction, which can be observed down to of $80 \mathrm{~cm}$ depth in good and average forwarding conditions (Prindulis, Lazdiņš, 2016). It is more feasible to use small forest machines in small felling sites in private forests. These machines can be transported with small trailers or even in a motorcar trailer, thus decreasing transportation costs. Ability to maneuver is another advantage of small machines, which allows forwarding without hauling roads, which are necessary for middle-class machines (Lazdin̦š, 2015).

Forest operations on soils with poor bearing capacity characterizes with increased time and fuel consumption and decreased efficiency of forwarding operations, resulting in considerable additional costs in forest management. The aim of this study is to estimate productivity of Vimek 610.2 forwarder, as well as to determine its impact on soil compaction in thinnings.

\section{MATERIALS AND METHODS}

Experimental sites were 2 forest stands, managed by Joint Stock company "Latvia State Forests" and located in northern part of Latvia nearby Engure (Table 1). Optimal forwarding conditions mean that soil bearing capacity is good, wet lowlands should not be crossed and it is not necessary to equip forwarder with tracks. Extreme forwarding conditions mean that soil bearing capacity is low, swamped, overflown areas should be crossed, and it is possible to haul logs without additional tracks only during prolonged periods of frost. Codes in species composition are: Ba - black alder, B - birch, A - aspen, $\mathrm{P}$ - Scots pine, S - Norway spruce; number before species code is percentage of growing stock, number after species code is age of trees. Distance between strip roads in both stands was $20 \mathrm{~m}$.

Table 1. Inventory data on study sites

\begin{tabular}{|c|c|c|c|c|c|c|c|c|c|c|}
\hline \multirow{2}{*}{ Compartment key } & \multirow{2}{*}{ Conditions } & \multicolumn{2}{|c|}{$\begin{array}{l}\text { Coordinates } \\
\text { LKS92 }\end{array}$} & \multirow{2}{*}{$\begin{array}{c}\text { Area, } \\
\text { ha }\end{array}$} & \multirow{2}{*}{$\begin{array}{l}\text { Peat } \\
\text { depth, } \\
\text { m }\end{array}$} & \multirow{2}{*}{$\begin{array}{c}\text { Species } \\
\text { composition }\end{array}$} & \multirow{2}{*}{$\begin{array}{c}\text { Growing } \\
\text { stock, } \mathrm{m}^{3} \\
\mathrm{ha}^{-1}\end{array}$} & \multirow{2}{*}{$\begin{array}{l}\text { Tree } \\
\text { height, } \\
\text { m }\end{array}$} & \multirow{2}{*}{$\begin{array}{c}\text { Tree } \\
\text { diameter, } \\
\mathrm{cm}\end{array}$} & \multirow{2}{*}{$\begin{array}{l}\text { Age } \\
\text { in } \\
\text { years }\end{array}$} \\
\hline & & $\mathrm{X}$ & $\mathrm{Y}$ & & & & & & & \\
\hline $\begin{array}{c}82-02-07-712-308 \\
29-0\end{array}$ & Extreme & 436040 & 348807 & 3.0 & 0.5 & $\begin{array}{c}\text { 7Ba2B1S35 } \\
+\mathrm{B} 73 \text { A35 } \\
\text { some P35 }\end{array}$ & 175 & 20 & 22 & 35 \\
\hline $\begin{array}{c}82-02-07-712-308 \\
26-0\end{array}$ & Optimal & 436005 & 348587 & 6.2 & 0.2 & $\begin{array}{c}\text { 5B43 4S58 } \\
1 \mathrm{Ba} 43 \text { some } \\
\text { P58 }\end{array}$ & 163 & 20 & 17 & 43 \\
\hline
\end{tabular}


The average daily temperature during forwarding trials was between -1.1 and $+9.9{ }^{\circ} \mathrm{C}$. In some days there was rainfall from $0.1 \mathrm{~mm}$ to $10.4 \mathrm{~mm}$. Amount of precipitation was evaluated according to the information available on Latvian Environment, Geology and Meteorology Agency official website from nearby observation station. Precipitation considerably deteriorated forwarding conditions. Soil was not frozen during the experiments.

The Vimek 610.2 Biocombi harwarder was used as a forwarder in trials. It was equipped with Mowi P25 crane, tracks on the rear axle and net chains on front wheels to enhance passability on soils with low bearing capacity. Additional pair of bunks was installed to forward short logs. Parameters of Vimek 610.2 Biocombi harwarder are shown in table 2.

Table 2. Parameters of Vimek 610.2 Biokombi harwarder

\begin{tabular}{|c|c|}
\hline Parameter & Value \\
\hline Unladen weight & 4.9 tonnes \\
\hline Engine & CAT C2.2T, $44 \mathrm{~kW} / 2700 \mathrm{rpm}$ \\
\hline Drive & Hydrostatic/mechanical \\
\hline Hydraulic system & Max flow $60 \mathrm{~L} / \mathrm{min}, 175$ bar \\
\hline Generator & $12 \mathrm{~V}, 60 \mathrm{~A}$ \\
\hline Front tire size & 500/60-22.5, one pair \\
\hline Rear tire size & 400/60-15.5, two pairs \\
\hline Dimensions & $\begin{array}{c}\text { Length: } 6.60 \mathrm{~m} \text {, cargo length } 3.00 \mathrm{~m} \text {, } \\
\text { loading area } 1.85 \mathrm{~m}^{2} \text {; } \\
\text { width: } 1.9 \mathrm{~m} \text {, number of fixed bunks ( } 3 \text { pairs) }\end{array}$ \\
\hline Load capacity & 5 tonnes \\
\hline Ground clearance & $40 \mathrm{~cm}$ \\
\hline Maximum driving speed & $18 \mathrm{~km} \mathrm{~h}^{-1}$ \\
\hline Crane & $\begin{array}{c}\text { Mowi P25 } \\
\text { max reach: } 5.2 \mathrm{~m} ; \\
\text { lifting capacity at } 5.2 \mathrm{~m}: 400 \mathrm{~kg}\end{array}$ \\
\hline
\end{tabular}

Time accounting during forwarding trials was carried out with a field PC Allegro CX equipped with time study program SDI. Working time consumed for each work operation was accounted separately for each crane cycle. In total, 15 operations were accounted (Table 3 ).

Table 3. Work operations during time study

\begin{tabular}{|c|c|c|}
\hline Working time category & Operation & Explanation \\
\hline Informative fields & Notes & Various notes, e.g., about breaks, drives, corridor change \\
\hline \multirow[t]{14}{*}{ Productive time } & Drive in & Drive into the stand without load \\
\hline & Reach & Reach logs with crane \\
\hline & Grip & Grip logs when loading in \\
\hline & Load in & Load logs into loading area \\
\hline & Rearrange load & Rearrange logs in loading area, put back fallen logs \\
\hline & Drive when loading in & Driving in stand during loading \\
\hline & Strip roads & Putting logging residues into strip roads \\
\hline & Drive out & Driving out from the stand with load \\
\hline & Reach when loading out & Reaching logs with crane when loading out \\
\hline & Grip when loading out & Gripping of logs during loading out in loading area \\
\hline & Load out & Putting logs into assortment pile \\
\hline & Rearrange assortments & $\begin{array}{l}\text { Rearranging of landing area (lining up of tops, putting fallen } \\
\qquad \text { logs into pile etc.) }\end{array}$ \\
\hline & Drive in landing area & Driving in landing area during loading out \\
\hline & Other & $\begin{array}{l}\text { Other work-related operations (small repairs and service, } \\
\text { checking driving conditions etc.) }\end{array}$ \\
\hline Unproductive time & Stop & $\begin{array}{l}\text { Operations unrelated to work (such as resting, answering } \\
\text { phone calls, etc.) }\end{array}$ \\
\hline
\end{tabular}


Logging in trial objects was carried out with petrol chainsaws, logging residues and tree tops were loaded into strip roads. Logging residues were used to fasten strip roads in places were wet areas had to be crossed. Additionally before the trials in extreme conditions Vimek 610.2 Biocombi bring logging residues from nearby stands with optimal forwarding conditions and loaded them into strip roads, especially in turning points and at landing area, where forwarding conditions were the most difficult. Two experienced operators participated in logging. Operators were working in 2 shifts, the length of a shift was 8 hours. Most of forwarded logs were 2.4-4.5 $\mathrm{m}$ in length. During forwarding operators loaded longer logs at the beginning and placed shorter ones between them. The accounting of the amount of hauled logs was carried out according to notes done by of the operator on filling of loads and hauled assortments.

Soil penetration resistance was measured in areas of felling sites where soil was not affected by forestry machines and on strip roads, using digital penetrologger Eijkelkamp. Measurements of penetration resistance were carried out every $7 \mathrm{~m}$. Data were logged in 0-80 cm depth, measurement step was $1 \mathrm{~cm}$.

Data were processed with MS Excel. The average statistical indicators were calculated with data analysis tool Descriptive Statistics. By the means of descriptive statistics average values and variance of the studied characteristics were estimated. Level of significance was evaluated using F-test.

An hourly cost model adopted for calculating of logging costs was used to calculate forwarding costs. The model is created in Latvia and based on the Swedish model FLIS (Lazdiņš et al., 2015, von Hofsten, et al. 2005). It is developed in LibreOffice Calc program and can be used for calculation of prime costs of felling and timber transportation, including system analysis. In calculations it was assumed that hauling is done in 2 shifts, each 8 hours long, by 2 operators. $15 \%$ of the working time constitutes unproductive time, when forwarder's engine is stifled. Transfer of the equipment between felling sites was subtracted from the working hours, assuming that it is done 50 times per year and each transfer lasts 2 hours. Operator salaries were calculated for 260 days, including vacation payment, per day costs, compensation for transportation. Training costs and health insurance were also included in the calculation.

\section{RESULTS}

In the forwarding trials with Vimek BioCombi 610.2 in total 56 loads were hauled, the average size of a load was $5.5 \mathrm{~m}^{3}$. The total volume of forwarded logs was $308 \mathrm{~m}^{3}$, mostly low grade hardwood logs and firewood was forwarded. The average hauling distance in compartment with extreme and optimal conditions was $150 \mathrm{~m}$ and $184 \mathrm{~m}$ accordingly. The main productivity indicators are shown in Table 4 and Table 5. Productivity values used in cost calculation are provided in Table 6 .

Table 4. Distribution of work time consumption (min. per load) except driving

\begin{tabular}{|c|c|c|c|c|c|c|c|c|c|c|c|c|}
\hline Plot & Reach & Grip & $\begin{array}{c}\text { Load } \\
\text { in }\end{array}$ & $\begin{array}{c}\text { Rearrange } \\
\text { load }\end{array}$ & $\begin{array}{c}\text { Drive } \\
\text { when } \\
\text { load in }\end{array}$ & $\begin{array}{c}\text { Strip } \\
\text { roads }\end{array}$ & $\begin{array}{c}\text { Reach } \\
\text { when load } \\
\text { out }\end{array}$ & $\begin{array}{c}\text { Grip } \\
\text { while } \\
\text { load out }\end{array}$ & $\begin{array}{c}\text { Load } \\
\text { out }\end{array}$ & $\begin{array}{c}\text { Rearrange } \\
\text { assortments }\end{array}$ & $\begin{array}{c}\text { Drive in } \\
\text { landing } \\
\text { area }\end{array}$ & Other \\
\hline Optimal & 0.23 & 0.26 & 0.60 & 0.09 & 0.34 & 0.14 & 0.20 & 0.28 & 0.43 & 0.10 & 0.27 & 0.31 \\
\hline Extreme & 0.18 & 0.28 & 0.46 & 0.06 & 0.28 & 0.86 & 0.12 & 0.15 & 0.27 & 0.04 & 0.02 & 1.71 \\
\hline
\end{tabular}

Table 5. Main productivity indicators, $\mathrm{min} . \mathrm{m}^{-3}$

\begin{tabular}{|l|l|l|l|l|}
\hline Plot & Total time spent & Productive time spent & Total time for loading in operations & Total time for load out operations \\
\hline Optimal & 6.11 & 6.03 & 1.73 & 1.28 \\
\hline Extreme & 7.03 & 6.23 & 3.66 & 0.61 \\
\hline
\end{tabular}

Table 6. Productivity values used in cost calculation

\begin{tabular}{|c|c|c|c|c|}
\hline Plot & Average load, $\mathrm{m}^{3}$ & $\begin{array}{c}\text { Time for Load in per 1 } \\
\text { load, min }\end{array}$ & $\begin{array}{c}\text { Time for Load out per 1 } \\
\text { load, min }\end{array}$ & Driving speed, $\mathrm{m} \mathrm{min}^{-1}$ \\
\hline Optimal & 4.5 & 110.4 & 3.8 & 59 \\
\hline Extreme & 5.5 & 20.4 & 3.7 & 37 \\
\hline
\end{tabular}

By assessing and comparing time consumption for hauling operations in optimal and extreme conditions, a significant difference was found for time consumed for operation Strip roads $(p=0.027<0.05)$. This is due to differences in hauling conditions - in extreme conditions time consumption to put harvesting residues and low grade logs into strip roads took 6 times more time than in optimal conditions. Comparison of time consumed for operation Other demonstrated significant difference $(p=0.003<0.05)$, which is associated with specific operations in extreme conditions like unloading in the stand to pull tractor out of mud. Additional time consumption is associated with evaluation of situation, when machine is stacked, and identification of technical issues, like damages of hydraulic systems (oil spills from pipes), which had to be replaced more often in extreme conditions.

The average productivity was calculated from time study results. In order to forward $1 \mathrm{~m}^{3}$ in trials with average hauling distance $181 \mathrm{~m} 6.95 \mathrm{~min}( \pm 0.65)$ were consumed, from whose $6.24( \pm 0.16)$ min were productive working time, 
which constitutes $89.8 \%$ from the total consumed time in hauling. Unproductive work time includes repairs (replacement of hydraulic pipes etc.). The average time consumption to load $1 \mathrm{~m}^{3}$ of logs was $3.49 \mathrm{~min}( \pm 1.36)$, for unloading - 0.67 $\min ( \pm 0.47)$, whereas for operations Drive in and Drive out $-1.90 \mathrm{~min}( \pm 0.49)$. A significant difference was found during comparison of the total time spent per $1 \mathrm{~m}^{3}$ in both plots $(\mathrm{p}=0.003<0.05)$, which can be explained with major differences in hauling conditions. The total time consumed for hauling $1 \mathrm{~m}^{3}$ of logs in optimal conditions was by $13 \%$ less than in extreme conditions. In cost calculation additional repairs should be considered when comparing operations in optimal and extreme conditions.

Soil compaction data from the forest stand with extreme forwarding conditions was analyzed. In total 8874 soil penetration resistance measurements were obtained. In order to characterize hauling conditions in study site, penetration resistance was calculated for 0-20 cm depth before hauling considering that the most of roots are located in this zone. Haulage conditions were considered extreme, when soil penetration resistance in $0-20 \mathrm{~cm}$ depth is below $0.5 \mathrm{MPa}$.

When assessing the whole soil profile down to $80 \mathrm{~cm}$ depth, difference in penetration resistance between strip roads and control sites is not statistically significant $(\mathrm{p}=0.32>0.05)$, which leads to a conclusion that in soils with low bearing capacity Vimek 610.2 does not cause additional soil compaction; however, there is considerably higher risk of formation of deep ruts, which can have adverse effect on development of forest stands, especially in spruce forests. The maximum penetration resistance of penetration slightly exceeds $2.5 \mathrm{MPa}$, but it can't be considered an obstacle for the tree root development, because significant disturbances appear only when resistance exceeds $3 \mathrm{MPa}$ and topsoil layers should be compacted. In order to detect a significant compaction in depth of $60-80 \mathrm{~cm}$, additional trials are necessary, because the soil penetration resistance can differ even in relatively close distance and number of measurements in the project might not be sufficient.

In prime cost calculation of Vimek 610.2 BioCombi services purchase of machine, personnel costs and operational costs are considered. Hauling conditions do not significantly impact prime cost, because most of it consists of personnel costs and investment costs. Proportion of operational costs from estimated total costs is $34 \%$.

Prime cost of forest haulage was calculated using data on forwarder productivity in trials. Prime cost was obtained using data from optimal and extreme forwarding plots. In optimal hauling conditions costs of hauling $1 \mathrm{~m}^{3}$ was $2.46 \mathrm{EUR}$, but in extreme conditions - 3.36 EUR. As a comparison, the prime cost of a middle class forwarder John Deere $810 \mathrm{D}$ is 3.36 EUR in similar conditions (Lazdiņš, 2014). However increase of forwarding distance reduces difference between small and medium-class forwarder. A summary of forest hauling prime cost calculations is given in Table 7.

Table 7. Prime cost of hauling in optimal and extreme conditions

\begin{tabular}{|c|c|c|}
\hline Indicator & Vimek forwarder in optimal conditions & Vimek forwarder in extreme conditions \\
\hline \multicolumn{3}{|c|}{ Technical costs, Eur per year } \\
\hline Investment & 13590 & 13590 \\
\hline Personnel costs & 30232.59 & 30233 \\
\hline Operational costs & 21490 & 21490 \\
\hline Total costs & 68578 & 68578 \\
\hline \multicolumn{3}{|c|}{ Planned profit margin, Eur per year } \\
\hline Planned profit & 3266 & 3266 \\
\hline \multicolumn{3}{|c|}{ Productivity, $\mathrm{m}^{3} \mathrm{E} 15 \mathrm{~h}^{-1}$} \\
\hline Productivity & 13.3 & 9.7 \\
\hline \multicolumn{3}{|c|}{ The amount of manufactured timber by a single technical unit $\mathrm{m}^{3}$ per year } \\
\hline Processed logs & 27895 & 20438 \\
\hline Logs under bark & 25092 & 22968.70 \\
\hline \multicolumn{3}{|c|}{ hauling costs } \\
\hline Logs under bark, EUR m ${ }^{-3}$ & 2.46 & 2.75 \\
\hline
\end{tabular}

\section{CONCLUSIONS}

- Productivity of forwarder Vimek 610.2 in trials, recalculated in time consumed for hauling $1 \mathrm{~m}^{3}$ timber at the same hauling distance $(181 \mathrm{~m})$ in optimal conditions is $6.03 \mathrm{~min}$ and in extreme conditions $-6.23 \mathrm{~min}$. Influence of hauling conditions is significant and it mainly consists of time consumed for strip road fastening and other operations necessary due to difficult hauling conditions.

- Evaluation of soil profile down to $80 \mathrm{~cm}$ depth demonstrated that the difference between the strip road and remaining stand in experimental site with extreme hauling conditions is not statistically significant $(\mathrm{p}=0.32)$, respectively on 
soils with low bearing capacity Vimek 610.2 forwarder does not cause soil compaction, however there is still risk of formation of deep ruts even if the machine is equipped with tracks. In areas with optimal soil bearing capacity significant compaction was detected nearby soil surface (down to $10 \mathrm{~cm}$ depth), however, it doesn't reach critical values hampering growth of roots. Long-term observations in thinned stands are needed in order to conclude, if reduced pressure on soil during hauling has a positive impact on further stand development.

- Prime costs of forest hauling with Vimek 610.2 in optimal conditions in $180 \mathrm{~m}$ distance is $2.46 € \mathrm{~m}^{-3}$, but in extreme conditions it is considerably higher $-3.36 € \mathrm{~m}^{-3}$. In practice prime cost will be influenced by machine workload, operator salaries and other factors, respectively obtained data should be used to evaluate relative impact of forwarding conditions and not as absolute values of the service cost.

\section{REFERENCES}

1. Hakansson, I., 1985. Soil compaction research in Sweden. Proceedings of Soil Compaction Conference, Ohio State University.

2. Hallonborg, U. 1979. Depth of ruts caused by forwarders. Logging research foundation. Stockholm.

3. Labelle, E.R., Jaeger, D. 2011. Soil Compaction Caused by Cut-to-Length Forest Operations and Possible Short-Term Natural Rehabilitation of Soil Density. Soil Science Society of America Journal, Vol. 6, pp.2314-2329. https://doi.org/10.2136/sssaj2011.0109

4. Lazdinšs A. 2014. Trials of plastic chain use in timber forwarding in commercial thinning. Research report, Latvian State Forest Research Institute „Silava”.

5. Lazdin̄š, A. 2015. Evaluation of productivity of Vimek Biocombi harwarder during forest thinning in young stands. Research report, Latvian State Forest Research Institute „Silava”.

6. Lazdin̦š, A. 2016. Productivity of Vimek harvester in birch plantations. Research report, Latvian State Forest Research Institute „Silava”.

7. Lazdin̄š, A., Liepiņš, J., Zimelis, A. 2008. Impact of forwarding conditions on costs of forwarders in final felling - results of soil compaction measurements. Research report, Latvian State Forest Research Institute „Silava”.

8. Lazdinšs, A., Zimelis, A., Kalēja, S. 2015. Production of biofuel in thinning of young stands, in first thinning and slope land cover with Moipu harvester head. Research report, Latvian State Forest Research Institute "Silava".

9. Liepiṇa, A., Lupiḳis, A., Sarkanābols, T., Lazdiṇš, A. 2014. Impact of forest machines on soil compaction and reforestation. Proceedings of the scientifically practical conference of the Faculty of Forestry, pp. 51-54, Latvia University of Agriculture.

10. Prindulis, U., Lazdinšs, A. 2016. Soil compaction in young stands during mechanized logging of biofuel and roundwood assortments, Forestry and wood processing. Proceedings of the International Scientific Conference: Research for Rural Development, Vol.2, pp. 69-76.

11. Sarmulis, Z., Saveljevs, A. 2015 Forest operations and technologies. LUA, Faculty of Forestry, Student's union "Šalkone", Jelgava.

12. Smith, K. A., Mullins, C. E. 2000. Soil and Environmental Analysis: Physical Methods. 2nd ed., Marcel Dekker Inc., New York.

13. Spinelli, R., Magagnotti, N., Di Fulvio, F., Bergström, D., Danelon, M., Alberti, G. 2014. Comparison of Cost Efficiency of Mechanized Fuel Wood Thinning Systems for Hardwood Plantations on Farmland. Croatian Journal of Forest Engineering, Vol. 35, pp.111-123.

14. von Hofsten. H., Lundström, H., Nordén, B., Thor, M. 2005. Biomass harvesting systems, analyses of seven final felling systems and four thinning systems. Research report, Skogforsk, Uppsala. 